\title{
Four quadruple metal-metal bonds lined up: linear nonachromium(II) metal string complexes $\dagger$
}

\author{
Rayyat H. Ismayilov, ${ }^{a b}$ Wen-Zhen Wang, ${ }^{a b}$ Rui-Ren Wang, ${ }^{a}$ Chen-Yu Yeh, ${ }^{c}$ Gene-Hsiang Lee ${ }^{a}$ and \\ Shie-Ming Peng*ab
}

Received (in Cambridge, UK) 6th October 2006, Accepted 30th November 2006

First published as an Advance Article on the web 20th December 2006

DOI: 10.1039/b614597c

Through a new pyrazine-modulated pentapyridyltetraamine ligand, $\mathrm{H}_{4} \mathrm{~N}_{9}-\mathrm{mpz}$, linear nonachromium(II) complexes with four quadruple metal-metal bonds were successfully obtained, and their structure, magnetic and electrochemistry properties were studied.

Extended metal atom chain (EMAC) complexes are very important to a fundamental understanding of metal-metal interactions and in potential applications such as molecular metal wire and switches. ${ }^{1}$ A series of tri-,${ }^{2}$ tetra-,${ }^{3}$ penta-,${ }^{4}$ hexa-,${ }^{5}$ hepta-,${ }^{6}$ and nona-nuclear ${ }^{7}$ metal string complexes have been synthesized by employing oligo- $\alpha$-pyridylamino ligands (Scheme 1). The typical structure of this family includes a linear metal chain, which is helically wrapped by four oligo- $\alpha$-pyridylamido ligands, with all the pyridine nitrogen and amido nitrogen atoms coordinated in a syn form. The adjacent pyridyl rings are not coplanar due to the repulsion of the $\beta-\mathrm{H}$ atoms, and the dihedral angle between adjacent pyridyl rings is about $45^{\circ}$. When an EMAC contains 17 metal atoms, the twisted, wrapping ligand will fulfil a single term around the metal array line and it is theoretically possible to extend the system to an infinite one-dimensional molecule. Thus synthesis of longer EMACs is one of the targets of research and great effort has been made towards this end over the past decade. However, synthetic difficulty increases and yield decreases with an increase in the number of metal atoms and length of the molecules. On the other hand, our previous research revealed that the longer the EMAC is, the more easily it undergoes oxidation, which destabilizes the compound. ${ }^{8}$ The longest EMAC molecule obtained to date contains nine metal atoms of nickel, ${ }^{7}$ seven of chromium $^{6}$ and cobalt, ${ }^{9}$ and five of ruthenium. Recently we designed a series of new ligands, pyrazine-modulated oligo$\alpha$-pyridylamino ligands, by including pyrazine instead of pyridine

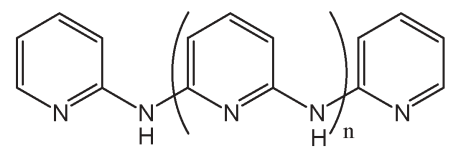

Scheme 1 Oligo- $\alpha$-pyridylamino ligands.

\footnotetext{
${ }^{a}$ Department of Chemistry, National Taiwan University, Taipei, Taiwan, ROC.E-mail: smpeng@ntu.edu.tw; Fax:+886283693765;

Tel: +886233661655

${ }^{b}$ Institute of Chemistry, Academia Sinica, Taipei, Taiwan, ROC

${ }^{c}$ Department of Chemistry, National Chung Hsing University, Taichung, Taiwan, ROC

$\dagger$ Electronic supplementary information (ESI) available: Fig. 1S,
} Scheme 2S. See DOI: 10.1039/b614597c ring(s) in the oligo- $\alpha$-pyridylamino ligands. ${ }^{10}$ The introduction of one or more nitrogen-rich aromatic rings, pyrazine, to the ligand significantly improves the reactivity leading to the EMAC, and the products are more resistant to oxidation than the relevant oligo$\alpha$-pyridylamino EMAC. Through the reaction of pyrazinemodulated pentapyridyltetraamine $\left(\mathrm{H}_{4}\right.$ peptea, Scheme $\left.1, n=3\right)$, we successfully obtained single crystals of linear nonachromium(II) complexes, which are the highest nuclearity chromium(II) EMACs reported to date. ${ }^{7}$ Here we report a new pyrazine-modulated pentapyridyltetraamine ligand, $N^{2}, N^{6}$-bis-[6-(pyridin-2-ylamino)pyridin-2-yl]pyrazine-2,6-diamine $\left(\mathrm{H}_{4} \mathrm{~N}_{9}-\mathrm{mpz}\right)+$ (Scheme $\left.2 \mathrm{~S}\right)$, and its nonachromium(II) complexes $\left[\mathrm{Cr}_{9}\left(\mu_{9}-\mathrm{N}_{9}-\mathrm{mpz}_{4} \mathrm{Cl}_{2}\right]\right.$ (1) $\S$ and $\left[\mathrm{Cr}_{9}\left(\mu_{9}-\mathrm{N}_{9}-\mathrm{mpz}\right)_{4}(\mathrm{NCS})_{2}\right](2)$. $\uparrow$

The ligand $\mathrm{H}_{4} \mathrm{~N}_{9}$-mpz was synthesized on the basis of the Buchwald's palladium-catalyzed procedures (Scheme 2S) via the cross-coupling of $\mathrm{N}$-pyridin-2-yl-pyridine-2,6-diamine and 2,6dichloropyrazine, ${ }^{11}$ and characterized by IR, ${ }^{1} \mathrm{H}$ NMR and $\mathrm{MS}(\mathrm{FAB})$. The chloride complex $\left[\mathrm{Cr}_{9}\left(\mu_{9}-\mathrm{N}_{9}-\mathrm{mpz}\right)_{4} \mathrm{Cl}_{2}\right]$ (1) was synthesized by the reaction of anhydrous $\mathrm{CrCl}_{2}$ with the ligand $\mathrm{H}_{4} \mathrm{~N}_{9}$-mpz in an argon atmosphere at high temperature (180 $200{ }^{\circ} \mathrm{C}$ ) employing naphthalene as solvent and $\mathrm{Bu}^{\mathrm{t}} \mathrm{OK}$ as a base to deprotonate the amine group. The thiocyanate species $\left[\mathrm{Cr}_{9}\left(\mu_{9}-\mathrm{N}_{9^{-}}\right.\right.$ $\left.\mathrm{mpz})_{4}(\mathrm{NCS})_{2}\right](2)$ was obtained through the substitution of axial chloride ligands from 1.

The crystal structures of $\mathbf{1}$ and $\mathbf{2}$ are shown in Fig. 1S and Fig. 1. || The molecule consists of nine $\mathrm{Cr}$ (II) atoms in a linear chain with the $\mathrm{M}-\mathrm{M}-\mathrm{M}$ bond angles in a range of $178-180^{\circ}$. The atoms of axial ligands bonded to the terminal metal atoms, chloride or nitrogen atoms of $\mathrm{NCS}^{-}$, are collinear with the $\mathrm{M}_{9}$ axis. The length of the whole molecule of $\mathbf{1}$ is $23 \AA$, and molecule 2 is $25 \AA$. This is the longest chain obtained since $\left[\mathrm{Ni}_{9}\left(\mu_{9}-\right.\right.$ peptea) ${ }_{4} \mathrm{Cl}_{2}$, which contains a nine-nickel chain. ${ }^{7}$ Four ligands wrapped around the metal string in syn-syn form as a nonadent anion helix. The $\mathrm{N}-\mathrm{Cr}-\mathrm{Cr}-\mathrm{N}$ torsion angles for adjacent $\mathrm{Cr}$ (II) are between 18 and $23^{\circ}$, and the average value of total torsion angles for one ligand, i.e. $\mathrm{N}-\mathrm{Cr}(1)-\mathrm{Cr}(1 \mathrm{~A})-\mathrm{N}$, is $159^{\circ}$. The $\mathrm{Cr}-\mathrm{Cr}$ bond distances fall into two categories, the shorter one is in the range 1.973-2.097 $\AA$ with an average of $2.025 \AA$, which is consistent with the reference values of the short limit for quadruple $\mathrm{Cr}-\mathrm{Cr}$ bonds (Table 1). ${ }^{12}$ The longer $\mathrm{Cr}-\mathrm{Cr}$ distances range from 2.397 to $2.497 \AA$. Thus complexes $\mathbf{1}$ and $\mathbf{2}$ are composed of four quadruple $\mathrm{Cr}-\mathrm{Cr}$ bonds and a single terminal $\mathrm{Cr}$ (II) atom coordinated in a pyramidal $\mathrm{Cl}-\mathrm{Cr}-\mathrm{N}_{4}$ unit, in the same style as tri- and pentachromium EMAC. It is noticeable that the four quadruple $\mathrm{Cr}-\mathrm{Cr}$ bonds and the single $\mathrm{Cr}$ (II) are aligned in a straight chain; this may result from the steric force of the ligand $\mathrm{H}_{4} \mathrm{~N}_{9}-\mathrm{mpz}$ for 


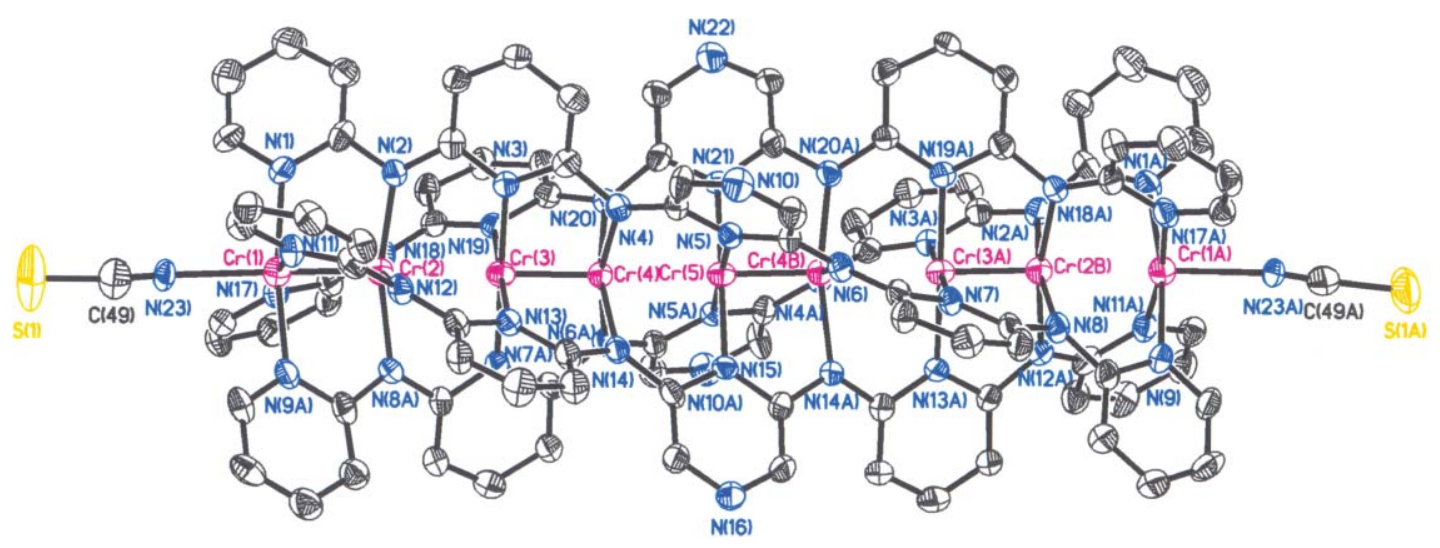

Fig. 1 The molecular structure of $\left[\mathrm{Cr}_{9}\left(\mu_{9}-\mathrm{N}_{9}-\mathrm{mpz}\right)_{4}(\mathrm{NCS})_{2}\right]$ (2). Label A represents symmetric related positions, and label B non-symmetric related positions (disordered positions). Thermal ellipsoids are drawn at the $30 \%$ probability level. The hydrogen atoms have been omitted for clarity.

Table 1 Selected bond lengths $(\AA)$ for $\mathbf{1}$ and $\mathbf{2}$

\begin{tabular}{|c|c|c|c|c|c|c|c|c|}
\hline & $\operatorname{Cr}(1)-\operatorname{Cr}(2)$ & $\operatorname{Cr}(2)-\operatorname{Cr}(3)$ & $\operatorname{Cr}(3)-\operatorname{Cr}(4)$ & $\operatorname{Cr}(4)-\operatorname{Cr}(5)$ & $\mathrm{Cr}(4 \mathrm{~B})-\mathrm{Cr}(5)$ & $\mathrm{Cr}(4 \mathrm{~B})-\mathrm{Cr}(3 \mathrm{~A})$ & $\mathrm{Cr}(3 \mathrm{~A})-\mathrm{Cr}(2 \mathrm{~B})$ & $\mathrm{Cr}(2 \mathrm{~B})-\mathrm{Cr}(1 \mathrm{~A})$ \\
\hline 1 & $2.097(4)$ & $2.425(4)$ & $2.024(3)$ & $2.397(3)$ & $2.017(3)$ & $2.404(4)$ & $2.046(4)$ & $2.475(4)$ \\
\hline 2 & $2.055(5)$ & $2.450(5)$ & $1.984(4)$ & $2.426(4)$ & $1.973(4)$ & $2.438(5)$ & $2.007(5)$ & $2.497(5)$ \\
\hline & $\mathrm{Cr}(1)-\mathrm{N}_{\mathrm{av}}$ & $\mathrm{Cr}(2)-\mathrm{N}_{\mathrm{av}}$ & $\mathrm{Cr}(3)-\mathrm{N}_{\mathrm{av}}$ & $\mathrm{Cr}(4)-\mathrm{N}_{\mathrm{av}}$ & $\mathrm{Cr}(5)-\mathrm{N}_{\mathrm{av}}$ & $\mathrm{Cr}(2 \mathrm{~B})-\mathrm{N}_{\mathrm{av}}$ & $\mathrm{Cr}(4 \mathrm{~B})-\mathrm{N}_{\mathrm{av}}$ & \\
\hline $\begin{array}{l}1 \\
2\end{array}$ & $\begin{array}{l}2.105(6) \\
2.089(9)\end{array}$ & $\begin{array}{l}2.038(6) \\
2.035(9)\end{array}$ & $\begin{array}{l}2.055(6) \\
2.047(8)\end{array}$ & $\begin{array}{l}2.034(7) \\
2.035(9)\end{array}$ & $\begin{array}{l}2.034(9) \\
2.032(11)\end{array}$ & $\begin{array}{l}2.029(7) \\
2.026(9)\end{array}$ & $\begin{array}{l}2.033(7) \\
2.033(9)\end{array}$ & \\
\hline
\end{tabular}

oligo- $\alpha$-pyridylamino ligands favoring linear metal string structures. However, a weak $\mathrm{Cr}-\mathrm{Cr}$ bond through the $\mathrm{Cr} 9$ core with $\sigma$-character was not excluded in spite of the long distances between quadruple $\mathrm{Cr}-\mathrm{Cr}$ bonds ( 2.397 to $2.497 \AA$ ), considering that the $\mathrm{Cr}-\mathrm{Cr}$ bond was observed in trichromium EMAC $\left[\mathrm{Cr}_{3}\left(\mu_{3^{-}}\right.\right.$ depa) ${ }_{4} \mathrm{Cl}_{2}$ ] even the $\mathrm{Cr}-\mathrm{Cr}$ distance is $2.378 \AA^{2 c}$ There are two equally occupied positions for $\operatorname{Cr}(2)$ and $\operatorname{Cr}(4)$, whereas $\operatorname{Cr}(1)$, $\mathrm{Cr}(3)$ and $\mathrm{Cr}(5)$ are not disordered. Thus the molecule is oriented in two directions as: $\mathrm{Cr} 1 \mathrm{Cr} 2---\mathrm{Cr} 3 \mathrm{Cr} 4---\mathrm{Cr} 5 \mathrm{Cr} 4 \mathrm{~B}---\mathrm{Cr} 3 \mathrm{Cr} 2 \mathrm{~B}---$ Cr1 or Cr1---Cr2BCr3---Cr4BCr5---Cr4Cr3---Cr2Cr1, and each form is adopted with an occupancy of $50 \%$.

The redox properties of EMACs are an important topic in the research of inherence of metal-metal bonding and their potential application as molecular devices. Previous studies showed that EMACs exhibited rich redox properties. The cyclic voltammograms show three oxidative waves at $E_{1 / 2}=+0.38,+0.50$, and $+0.92 \mathrm{~V}$ for 1 , and $E_{1 / 2}=+0.42,+0.52$, and $+0.94 \mathrm{~V}$ for 2 (Fig. 2). The first and second oxidation processes are overlapped and can be well resolved by using differential pulse techniques. All electrochemical processes are reversible and involve one-electron abstraction as evidenced by thin-layer spectroelectrochemical measurements. ${ }^{13}$ Displacement of chlorides with thiocyanates results in slightly anodic shifts. The first oxidation peaks for both 1 and $\mathbf{2}$ corresponded to the loss of one electron from isolated $\mathrm{Cr}$ (II) according to the research on oxidized products of complexes $\mathrm{Cr}_{3}\left(\mu_{3} \text {-dpa }\right)_{4} \mathrm{Cl}_{2}[\mathrm{Hdpa}=$ di(2-pyridyl $)$ amine $]$ and $\mathrm{Cr}_{5}\left(\mu_{5} \text {-tpda }\right)_{4} \mathrm{Cl}_{2}$ $\left[\mathrm{H}_{2}\right.$ tpda $=N, N^{\prime}$-bis( $\alpha$-pyridyl)-2,6-diaminopyridine $]$, and the resulting species was $\mathrm{Cr}_{9}{ }^{19+}$ with the backbone $\left(\mathrm{Cr}^{\mathrm{II}} \equiv \mathrm{Cr}^{\mathrm{II}}\right)_{4}-\mathrm{Cr}^{\mathrm{III}} \cdot{ }^{2 d, 4 a}$

The magnetic behaviour of $\mathbf{1}$ and $\mathbf{2}$ are similar and obey the Curie-Weiss law. Plots of thermal magnetic susceptibility and $\chi_{\mathrm{M}} T$ are shown in Fig. 3. The $\chi_{\mathrm{M}} T$ values of $\mathbf{1}$ and $\mathbf{2}$ at room temperature $(300 \mathrm{~K})$ were 3.20 and $3.11 \mathrm{emu} \mathrm{K} \mathrm{mol} \mathrm{mo}^{-1}$, respectively, which correspond to the value of the quintet ground state (for four unpaired electrons $\chi_{\mathrm{M}} T=3 \mathrm{emu} \mathrm{K} \mathrm{mol}^{-1}$ ). Based on the structural results, the first approximation attributes the magnetic contribution only to the high-spin, terminal $\mathrm{Cr}$ (II) atom that is non-bonded to other $\mathrm{Cr}(\mathrm{II})$ atoms, and the $\mathrm{CrCr}$ bond is diamagnetic with eight electrons localized within the $\mathrm{Cr}-\mathrm{Cr}$ quadruple bond.

From 300 to $16 \mathrm{~K}, \chi_{\mathrm{M}} T$ for both $\mathbf{1}$ and $\mathbf{2}$ decreased only slightly upon cooling. A fit with the Curie-Weiss Law gave $g=2.07$ and $\theta=-5.54 \mathrm{~K}$ for 1 and $g=2.03$ and $\theta=-2.20 \mathrm{~K}$ for 2 . An obvious decrease of $\chi_{\mathrm{M}} T$ was observed below $16 \mathrm{~K}$, which was due to zero-field splitting and an incorporation of intermolecular interaction.

In summary, through the reaction of the pyrazine-modulated pentapyridyltetraamine ligand, we successfully obtained single crystals of linear nonachromium complexes, which are the highest

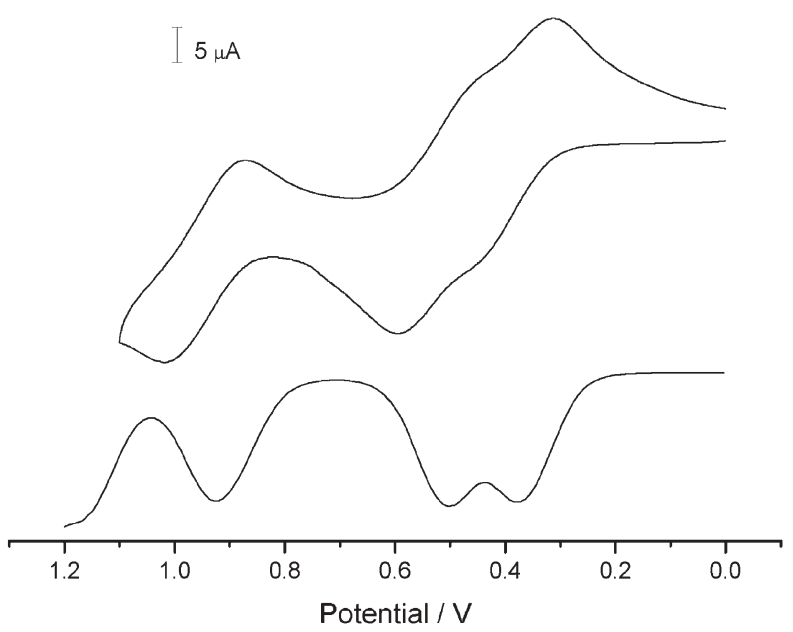

Fig. 2 Cyclic voltammogram (top) and differential pulse voltammograph (bottom) of $\mathbf{1}$ in $\mathrm{CH}_{2} \mathrm{Cl}_{2}$ with $0.1 \mathrm{M}$ TBAP. 


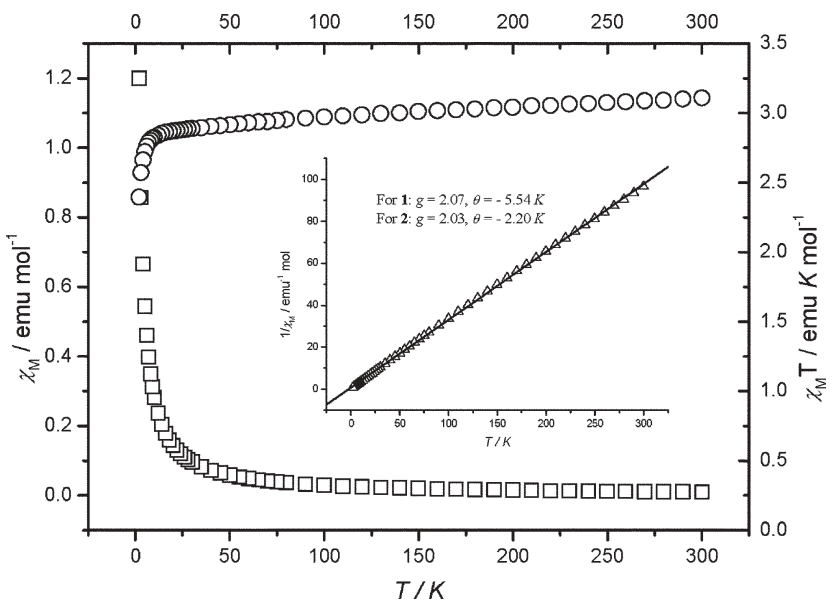

Fig. 3 Temperature-dependent $\chi_{\mathrm{M}} T(\bigcirc$, right axis) and molar magnetic susceptibility ( $\square$, left axis) for compound 2 . Inset: reciprocal dependence of the magnetic susceptibility on temperature. The solid lines result from least-square fits of the Curie-Weiss Law.

nuclearity EMACs reported to date. Further investigations on high nuclearity chromium(II) EMACs with pyrazine-modulated ligands are currently underway in our group.

The authors thank the National Science Council of the Republic of China for financial support and Mr Shih-Chi Wang for his help with magnetic measurement.

\section{Notes and references}

\$ Synthesis of $N^{2}, N^{6}$-bis-[6-(pyridin-2-ylamino)pyridin-2-yl]pyrazine-2,6diamine $\left(\mathrm{H}_{4} \mathrm{~N}_{9}-\mathrm{mpz}\right)$. The reaction of 2,6-dichloropyrazine $(10 \mathrm{~g}$, $0.067 \mathrm{~mol})$ and $N$-pyridin-2-yl-pyridine-2,6-diamine $(29.96 \mathrm{~g}, 0.061 \mathrm{~mol})$ in the presence of $\operatorname{Pd}_{2}(\mathrm{dba})_{3}(1.229 \mathrm{~g}, 2 \mathrm{~mol} \%)$, BINAP $(1.671 \mathrm{~g}, 4 \mathrm{~mol} \%)$ and $\mathrm{Bu} \mathrm{t}^{\mathrm{ONa}}(21.67 \mathrm{~g}, 0.225 \mathrm{~mol})$ in benzene $(600 \mathrm{~mL})$ for $72 \mathrm{~h}$ gave $\mathrm{H}_{4} \mathrm{~N}_{9^{-}}$ mpz. The crude product was recrystallized from acetone and gave pure $\mathrm{H}_{4} \mathrm{~N}_{9}$-mpz as a light yellow solid (yield $30.6 \%$ ). IR (KBr) $v / \mathrm{cm}^{-1}: 3402 \mathrm{~m}$, $3270 \mathrm{~m}, 3191 \mathrm{~m}, 3103 \mathrm{~m}, 3050 \mathrm{~m}, 1598 \mathrm{~m}, 1558 \mathrm{~m}, 1516 \mathrm{~m}, 1434 \mathrm{vs}, 1354 \mathrm{~m}$, $1301 \mathrm{~m}, 1260 \mathrm{~m}, 1246 \mathrm{~m}, 1226 \mathrm{~m}, 1192 \mathrm{~m}, 1151 \mathrm{~m}, 996 \mathrm{w}, 771 \mathrm{~m}, 668 \mathrm{w} ; \mathrm{UV} / \mathrm{Vis}$ $\left(\right.$ DMF) $\lambda_{\max } / \mathrm{nm}\left(\varepsilon / \mathrm{dm}^{3} \mathrm{~mol}^{-1} \mathrm{~cm}^{-1}\right): 270\left(4.33 \times 10^{4}\right), 321\left(2.48 \times 10^{4}\right)$, $370\left(3.70 \times 10^{4}\right), 467\left(7.46 \times 10^{2}\right) ;{ }^{1} \mathrm{H}$ NMR $\left(400 \mathrm{MHz},\left(\mathrm{CD}_{3}\right)_{2} \mathrm{SO}\right): \delta 9.42$ (s, 4H), $8.57(\mathrm{~s}, 2 \mathrm{H}), 8.20-8.19(\mathrm{~m}, 2 \mathrm{H}), 7.81-7.79(\mathrm{~d}, J=8.46 \mathrm{~Hz}, 2 \mathrm{H})$, $7.64-7.60(\mathrm{~m}, 2 \mathrm{H}), 7.56-7.52(\mathrm{t}, J=8.01 \mathrm{~Hz}, 2 \mathrm{H}), 7.23-7.19(\mathrm{t}, J=8.12 \mathrm{~Hz}$, $4 \mathrm{H}), 6.86-6.83(\mathrm{~m}, 2 \mathrm{H})$; MS(FAB): $m / z(\%) 449(45)[\mathrm{M}]^{+}$; EA $(\%)$ $\mathrm{C}_{24} \mathrm{H}_{20} \mathrm{~N}_{10} \cdot \mathrm{CH}_{3} \mathrm{OH}$ : calc. C 62.49, H 5.03, N 29.15; found: C $62.45, \mathrm{H}$ $4.67, \mathrm{~N} 29.30 \%$.

$\S$ Synthesis of $\left[\mathrm{Cr}_{9}\left(\mu_{9}-\mathrm{N}_{9}-\mathrm{mpz}\right)_{4} \mathrm{Cl}_{2}\right]$ (1). Anhydrous $\mathrm{CrCl}_{2}(0.637 \mathrm{~g}$, $5.1 \mathrm{mmol}), \mathrm{H}_{4} \mathrm{~N}_{9}-\mathrm{mpz}(0.448 \mathrm{~g}, 1.0 \mathrm{mmol})$ and naphthalene $(40 \mathrm{~g})$ were heated at $c a .170-180{ }^{\circ} \mathrm{C}$ under argon and then a solution of potassium tert-butoxide $(0.561 \mathrm{~g}, 5.0 \mathrm{mmol})$ in $n$-butyl alcohol $(4 \mathrm{~mL})$ was added dropwise. After reaction $n$-hexane was added to wash out the naphthalene. Compound 1 was extracted and recrystallized in $\mathrm{CH}_{2} \mathrm{Cl}_{2}$-benzene $(1: 1)$ (yield $1.0 \%$ ). IR $(\mathrm{KBr}) v / \mathrm{cm}^{-1}: 1603 \mathrm{~m}, 1582 \mathrm{~m}, 1550 \mathrm{~m}, 1447 \mathrm{~m}, 1410 \mathrm{~s}$, $1353 \mathrm{~m}, 1326 \mathrm{~s}, 1270 \mathrm{~m}, 1197 \mathrm{~m}, 1156 \mathrm{~m}, 1104 \mathrm{w}, 1118 \mathrm{w}, 1046 \mathrm{w}, 1020 \mathrm{~m}, 779 \mathrm{~m}$, 736m, 668m; UV/Vis $\left(\mathrm{CH}_{2} \mathrm{Cl}_{2}\right) \lambda_{\max } / \mathrm{nm}\left(\varepsilon / \mathrm{dm}^{3} \mathrm{~mol}^{-1} \mathrm{~cm}^{-1}\right): 230(1.11 \times$ $\left.10^{5}\right), 278\left(1.39 \times 10^{5}\right), 349\left(9.36 \times 10^{4}\right), 369\left(9.46 \times 10^{4}\right), 390(9.73 \times$ $\left.10^{4}\right), 600\left(6.20 \times 10^{3}\right), 756\left(6.82 \times 10^{3}\right), 809\left(8.34 \times 10^{3}\right) ; \mathrm{MS}(\mathrm{FAB}): \mathrm{m} / \mathrm{z}$ (\%) $2316(65)[\mathrm{M}]^{+}, 2283(100)[\mathrm{M}-\mathrm{Cl}]^{+}$; EA (\%) $\left[\mathrm{Cr}_{9}\left(\mu_{9}-\mathrm{N}_{9^{-}}\right.\right.$ $\left.\mathrm{mpz})_{4} \mathrm{Cl}_{2}\right] \cdot \mathrm{CH}_{2} \mathrm{Cl}_{2} \cdot 2 \mathrm{CH}_{3} \mathrm{OH}$ : calc. C $48.23, \mathrm{H} 3.03, \mathrm{~N} 22.72$; found: $\mathrm{C}$ $48.38, \mathrm{H} 3.38$, N $21.94 \%$.

- Synthesis of $\left[\mathrm{Cr}_{9}\left(\mu_{9}-\mathrm{N}_{9}-\mathrm{mpz}\right)_{4}(\mathrm{NCS})_{2}\right](2)$. $\left[\mathrm{Cr}_{9}\left(\mu_{9}-\mathrm{N}_{9}-\mathrm{mpz}_{4} \mathrm{Cl}_{2}\right](0.03 \mathrm{~g}\right.$, $0.013 \mathrm{mmol})$ and NaNCS $(0.004 \mathrm{~g}, 0.051 \mathrm{mmol})$ in $\mathrm{CHCl}_{3}(30 \mathrm{~mL})$ were stirred for $2 \mathrm{~d}$. The solvent was removed under reduced pressure and the product recrystallized from a $\mathrm{CHCl}_{3}$-diethyl ether solution (1:4). Deep red-brown crystals were obtained (yield $82 \%$ ). IR (KBr) $v / \mathrm{cm}^{-1}: 3418 \mathrm{~m}$, br, 2036m, 1603m, 1582m, 1551m, 1472m, 1409s, 1325s, 1268m, 1196m, 1155s,
1119 w, 1103w, 1020m, 972w, 834w, 778m, 736m, 648w; UV/Vis $\left(\mathrm{CH}_{2} \mathrm{Cl}_{2}\right)$ $\lambda_{\max } / \mathrm{nm}\left(\varepsilon / \mathrm{dm}^{3} \mathrm{~mol}^{-1} \mathrm{~cm}^{-1}\right): 236\left(1.05 \times 10^{5}\right), 280\left(1.32 \times 10^{5}\right), 361(9.13$ $\left.\times 10^{4}\right), 393\left(9.50 \times 10^{4}\right), 655\left(3.80 \times 10^{3}\right), 757\left(7.99 \times 10^{3}\right), 809(8.27 \times$ $\left.10^{3}\right)$; MS(FAB): $m / z(\%) 2360$ (4) $[\mathrm{M}-\mathrm{NCS}]^{+}$; EA $(\%)\left[\mathrm{Cr}_{9}\left(\mu_{9}-\mathrm{N}_{9^{-}}\right.\right.$ mpz $\left.)_{4}(\mathrm{NCS})_{2}\right]$ : calc. C 40.49, H 2.46, N 30.11; found: C 40.66, H 2.32, N $29.42 \%$.

II Crystal data for 1: $\left[\mathrm{Cr}_{9}\left(\mu_{9}-\mathrm{N}_{9}-\mathrm{mpz}\right)_{4} \mathrm{Cl}_{2}\right] \cdot 2 \mathrm{C}_{6} \mathrm{H}_{6} \cdot 2 \mathrm{C}_{6} \mathrm{H}_{14} \cdot \mathrm{C}_{2} \mathrm{H}_{5} \mathrm{OC}_{2} \mathrm{H}_{5}$, $M_{\mathrm{w}}=2719.45$, monoclinic, space group $C 2 / c, a=44.392(3), b=$ 14.3963(10), $c=18.6471(12) \AA, \beta=95.391(4)^{\circ}, V=11864.3(14) \AA^{3}, Z=4$, $\mu=0.907 \mathrm{~mm}^{-1}, 46502$ reflections collected, 10382 independent, final $R 1=0.0788$ for $I>2 \sigma(I) ; w R 2=0.2618$ for all data. Crystal data for $\mathbf{2}$ : $\left[\mathrm{Cr}_{9}\left(\mu_{9}-\mathrm{N}_{9}-\mathrm{mpz}\right)_{4}(\mathrm{NCS})_{2}\right] \cdot 2 \mathrm{C}_{6} \mathrm{H}_{14} \cdot \mathrm{CHCl}_{3}, M_{\mathrm{w}}=2653.74$, monoclinic, space group $C 2 / c, a=43.5722(13), b=14.4390(5), c=19.2834(6) \AA$, $\beta=$ 98.1689(17) ${ }^{\circ}, V=12008.8(7) \AA^{3}, Z=4, \mu=0.948 \mathrm{~mm}^{-1}, 31810$ reflections collected, 10533 independent, final $R 1=0.1077$ for $I>2 \sigma(I), w R 2=$ 0.3432 for all data. Structures of $\mathbf{1}$ and $\mathbf{2}$ were solved both by $C 2 / c$ and $C c$ space groups, and the results showed that in both compounds the $C 2 / c$ data are superior. The details were included in CIF files. CCDC 623204 and 623205. For crystallographic data in CIF or other electronic format see DOI: $10.1039 / \mathrm{b} 614597 \mathrm{c}$.

1 J. F. Berry, F. A. Cotton, L. M. Daniels and C. A. Murillo, J. Am. Chem. Soc., 2002, 124, 3212; S.-Y. Lin, I.-W. P. Chen, C.-H. Chen, M.-H. Hsieh, C.-Y. Yeh, T.-W. Lin, Y.-H. Chen and S.-M. Peng, J. Phys. Chem. B, 2004, 108, 959; I.-W. P. Chen, M.-D. Fu, W.-H. Tseng, J.-Y. Yu, S.-H. Wu, C.-J. Ku, C.-H. Chen and S.-M. Peng, Angew. Chem., Int. Ed., 2006, 45, 5414.

2 (a) C.-K. Kuo, J.-C. Chang, C.-Y. Yeh, G.-H. Lee, C.-C. Wang and S.-M. Peng, Dalton Trans., 2005, 3696; (b) B. Bénard, J. F. Berry, F. A. Cotton, C. Gaudin, X. López, C. A. Murillo and M.-M. Rohmer, Inorg. Chem., 2006, 45, 3932; (c) J. F. Berry, F. A. Cotton, T. Lu, C. A. Murillo, B. K. Roberts and X. Wang, J. Am. Chem. Soc., 2004, 126, 7082; (d) R. Clérac, F. A. Cotton, L. M. Daniels, K. R. Dunbar, C. A. Murillo and I. Pascual, Inorg. Chem., 2000, 39, 752; (e) J. F. Berry, F. A. Cotton, L. M. Daniels, C. A. Murillo and X. Wang, Inorg. Chem., 2003, 42, 2418.

3 F. A. Cotton, L. M. Daniels, C. A. Murillo and X. Wang, Chem. Commun., 1998, 39; S.-Y. Lai, T.-W. Lin, Y.-H. Chen, C.-C. Wang, G.-H. Lee, M.-H. Yang, M.-K. Leung and S.-M. Peng, J. Am. Chem. Soc., 1999, 121, 250.

4 (a) H.-C. Chang, J.-T. Li, C.-C. Wang, T.-W. Lin, H.-C. Lee, G.-H. Lee and S.-M. Peng, Eur. J. Inorg. Chem., 1999, 1243; (b) J. F. Berry, F. A. Cotton, C. S. Fewox, T. Lu, C. A. Murillo and X. Wang, Dalton Trans., 2004, 2297; (c) C.-Y. Yeh, Y.-L. Chiang, G.-H. Lee and S.-M. Peng, Inorg. Chem., 2002, 41, 4096; (d) C.-Y. Yeh, C.-H. Chou, K.-C. Pan, C.-C. Wang, G.-H. Lee, Y. O. Su and S.-M. Peng, J. Chem. Soc., Dalton Trans., 2002, 2670; (e) J. F. Berry, F. A. Cotton, P. Lei, T. Lu and C. A. Murillo, Inorg. Chem., 2003, 42, 3534.

5 C.-H. Chien, J.-C. Chang, C.-Y. Yeh, G.-H. Lee, J.-M. Fang, Y. Song and S.-M. Peng, Dalton Trans., 2006, 3249; C.-H. Chien, J.-C. Chang, C.-Y. Yeh, G.-H. Lee, J.-M. Fang and S.-M. Peng, Dalton Trans., 2006, 2106.

6 Y.-H. Chen, C.-C. Lee, C.-C. Wang, G.-H. Lee, S.-Y. Lai and S.-M. Peng, Chem. Commun., 1999, 1667; S.-Y. Lai, C.-C. Wang, Y.-H. Chen, C.-C. Lee, Y.-H. Liu and S.-M. Peng, J. Chin. Chem. Soc., 1999, 46, 477.

7 S.-M. Peng, C.-C. Wang, Y.-L. Jang, Y.-H. Chen, F.-Y. Li, C.-Y. Mou and M.-K. Leung, J. Magn. Magn. Mater., 2000, 209, 83.

8 C.-Y. Yeh, C.-C. Wang, Y.-H. Chen and S.-M. Peng, in Redox Systems Under Nano-Space Control, ed. T, Hirao, Springer, Germany, 2006, ch. 5 .

9 W.-Z. Wang, R. H. Ismayilov, G.-H. Lee, I. P.-C. Liu, C.-Y. Yeh and S.-M. Peng, Dalton Trans., 2006, DOI: 10.1039/b614661a.

10 R. H. Ismayilov, W.-Z. Wang, G.-H. Lee and S.-M. Peng, Dalton Trans., 2006, 478 .

11 S. Wagaw and S. L. Buchwald, J. Org. Chem., 1996, 61, 7240; M.-K. Leung, A.-B. Mandal, C.-C. Wang, G.-H. Lee, S.-M. Peng, H.-L. Cheng, G.-R. Her, I. Chao, H.-F. Lu, Y.-C. Sun, M.-Y. Shiao and P.-T. Chou, J. Am. Chem. Soc., 2002, 124, 4287.

12 F. A. Cotton, C. A. Murillo and I. Pascual, Inorg. Chem., 1999, 38, 2182.

13 D. F. Rohrbach, E. Deutsch, W. R. Heineman and R. F. Pasternack, Inorg. Chem., 1977, 16, 2650. 